\title{
PIKMA Role in Improving The Knowledge of Free Sex
}

\author{
$\underline{\text { Kartika Utami1); Siti Rofi'ah'1); Nuril Nikmawati1)) }}$ \\ kartikachristo@gmail.com
}

\begin{abstract}
Background : Youth is an asset and the future generation, so that young people had an important role to determine the future of Indonesia. Adolescents tend to want to know new things, so comes the behavioral want to try, and if it is driven by sexual stimulation can lead teens to get in on premarital sexual intercourse (sex). The purpose of this study was to determine the effectiveness of Pikma role in improving knowledge about sex with using the media module, singing Goldapersas, and leaflets to the students of SMK Negeri 2 Magelang Year 2019

Methods : quasy experimental research type with pretest post test control group design. The population in this study as many as 282 people. a sample of 165 people. Data analysis by Kruskal Wallis and Mann Whitney Post Hoc test.

Results: The results showed that there are different levels of knowledge between variables (singing Goldapersas, modules and leaflets) after being given health education, $p=0.000$. The results of this study were expected to make teenagers more active in seeking information about reproductive health, in addition to the teachers also need to improve and equip students with knowledge about sex.

Conclusion : Media module is more effective in supporting roles Pikma to increase knowledge about sex in adolescents.
\end{abstract}

Keyword: Knowledge, Media Singing Golapersas, Media Module, Free Sex

\section{1,2,3) Midwifery Study Program of Magelang, Health Polytechnic of Semarang, Indonesia Jl. Perintis Kemerdekaan, Magelang, Indonesia}

Background. Teens are an asset and the future generation, so that young people had an important role to determine the future of Indonesia (BKKBN and BPS, 2013), great curiosity, love adventure and challenges as well as tend to dare to risk for his actions without prior deliberation become distinctive properties owned by teenagers. Often in life, youth is not right to make decisions that can plunge into risky behavior. It will bring them to bear the consequences of short-term and longterm in a variety of physical and psychosocial health problems.

In adolescence, physical and sexual changes that can increase the sense of sexual attraction towards the opposite sex and sex drive (Lembaga Demografi FEB UI, 2017), Adolescents tend to want to know new things, so comes the behavioral want to try, and if it was driven by sexual stimulation can lead teens to get in on premarital sexual intercourse (sex) (Marmi, 2015).

Global information (audio-visual media exposure) are more easily accessible, if not controlled properly can provide a considerable influence on the lives of teenagers. The impacts that may provoke adolescents to adopt unhealthy habits, and deliver the custom highrisk sexual behavior because teenagers do not have accurate knowledge (Marmi, 2015).

Premarital sex among adolescents affects the occurrence of early pregnancy and transmission of sexually transmitted diseases. Teen choice made during this period will determine future success. Therefore, it is important to understand adolescent things that must be prepared in order to become an adult who successfully face the challenges of the world (Lembaga Demografi FEB UI, 2017).

Based on the data and information from (Kemenkes RI, 2018), Known to the estimated number of people of Indonesia in 2017 as many as 261890872 inhabitants, $17.15 \%$ of the total population in Indonesia is a young population (teenagers). In connection with sex incident-free, according to BKKBN, BPS, \& (Kemenkes RI, 2018), unmarried young women (15-19 years) who have ever had sexual intercourse by $0.9 \%$, or some 6,750 people and unmarried young men (15-19 years) by $3.6 \%$, or some 7,713 people. In addition, the high incidence of promiscuity in Indonesia in 2017 is shown by the teenage pregnancy rate of $15-19$ years to 33 per 1000 
live births in women (BKKBN, 2018). Meanwhile, in Central Java reached 34 per 1000 live births in women (BKKBN, 2018). Based on the data and information from (Dinkes Magelang, 2018) free sex figure recorded 25 adolescents with a case of premarital pregnancy and counseling. In addition to these two cases, the promiscuity's incidence in teenagers unreported in Magelang City Health Department.

Based on the results of preliminary studies conducted in SMK Negeri 2 Magelang showed $70 \%$ of students have a girlfriend and the courtship behavior $70 \%$ of students admitted that the style of courting teenagers today over the limit, there are $40 \%$ of students like dating the current state of quiet, $60 \%$ never even often hand in hand, $20 \%$ had been kissed, kissing lips $10 \%$, and $10 \%$ had sexual intercourse. This is very alarming because according to (Hasan and Nasma, 2008) Sexual activity starts than just handrails, kissing, cuddling, petting, to have sexual intercourse (sexual intercourse). And to knowledge about sex, some have less knowledge marked by answering a questionnaire is not exactly on topic causes and how to avoid promiscuity.

A teenager can be said to be qualified if they have prepared themselves with many provisions of the sciences that is able to bring out their inner producvity (Lembaga Demografi FEB UI, 2017). According to the results of recent research carried out by the ((Luthfi, 2015) Said that the level of knowledge of adolescents will increase with the extension services using audiovisual media. Audiovisual media can be a tool or tools see (visual aids) are useful to stimulate the eye (vision) as a module, and hearing aids (audio aids) that helps stimulate the auditory such as a song or chant. The use of media will facilitate the receipt of information as the most knowledge received through the senses (Notoatmodjo, 2012).

Rofi'ah, Widatiningsih, \& Vitaningrum, (2017) the research also said that health education using effective peer group on the level of knowledge. Pikma role in this highly influential that not only guide and nurture, but as a motivator so it can pass health information to other members, especially teenagers when viewed in terms of free sex case (Notoatmodjo, 2012).

According to BKKBN (2009), PIKMA be managed container activities of, by and for the students to provide information and counseling services. PIKMA scope covers aspects of activities to disseminate information one of them is about sexuality. Diploma III Midwifery Study Program of Magelang Health Polytechnic of Semarang there have been PIKMA Delima Student Activity Unit which was established in 2014 and in 2018 had a membership of 30 people.

Thus, researchers as one of the students in health studies program in Magelang interested in cooperation with the Student Activity Unit PIKMA Delima Midwifery Study Program of Magelang Health Polytechnic of Semarang to develop and promote the organization PIKMA Delima. Researchers want to improve the knowledge of students of SMK Negeri 2 Magelang who did not get a lesson on reproductive health, especially free sex, in order to be used as anticipated, by using the media module and singing Goldapersas to create a quality youth and away from free sex.

Methods. This type of research was quasy experimental study with nonequivalent control group design. The population were students of class X SMK Negeri 2 Magelang, amounting to 282 students. The sampling technique in this study is simple random sampling using the formula and the results obtained sample slovin 165 students.

Implementation of research begins with a pretest data collection using questionnaires and continued with health education's provision using media modules, leaflets and chanting Goldapersas, and was followed by a posttest

\section{Result and Discussion.}

Table 1 Distribution of frequency of adolescent knowledge level before being given health education with media modules

\begin{tabular}{lcc}
\hline Category & Frequency & percentage \\
\hline Well & 24 & 43.6 \\
Enough & 29 & 52.7 \\
Less & 2 & 3.6 \\
\hline Total & 55 & 100.00 \\
\hline
\end{tabular}

Based on table 1 shows that the level of knowledge of adolescents before being given a health education module media category was dominated by quite as much as 29 students (52.7\%). 
The results showed that the level of knowledge of adolescents before being given a health education module media dominated the category enough, this is because the student ever to access information about reproductive health through the internet. This is according to research conducted by Sherlyanita \& Rakhmawati (2016) with the title Effect and Activity Patterns of Use Internet And Social Media at SMPN 52 Surabaya, which says that the goal of most students use the Internet is for the purpose of learning or education. Learning accessible to students with using the Internet, one on reproductive health that is free sex. aligned with Ardina (2017) in his research titled Access Reproductive Health Information, said that reproductive health information needed by respondents with the highest percentage of information about the dangers of drug use, followed by the language information promiscuity, HIV / AIDS and the dangers of abortion. In addition, the study also said that the majority of respondents use the Internet to find information on a variety of issues related to reproductive health.

Table 2 Distribution of the frequency of adolescent knowledge level after the given health education with media modules

\begin{tabular}{lcc} 
Category & Frequency & percentage \\
\hline Well & 55 & 100.00 \\
Enough & - & - \\
Less & - & - \\
\hline Total & 55 & 100.00 \\
\hline
\end{tabular}

Based on Table 2 indicate that the level of knowledge of adolescents after given health education modules media were dominated by either category as many as 55 students (100\%).

The results showed that the level of knowledge of adolescents after given health education with media modules all have good knowledge. Research result Johariyah \& Mariati (2018) entitled Effectiveness Reproductive Health Extension Module With Giving Teens Against Knowledge Amendment which states that there are significant differences to changes in adolescent reproductive health knowledge before and after health education. In another study conducted by Kusuma \& Budiono (2017) entitled Media Module Braille Against Nutritional Knowledge, attitudes, and practices Blind Spot Early Childhood said that the development of nutritional Braille module effective in improving knowledge and attitudes breakfast on blind children with values of $p<0.01$, respectively. When the delivery of health education by using media modules, delivery of material was performed for 30 minutes. Researchers deploy the module at each respondent. Respondents seemed enthusiastic in scrutinizing each sentence and the image on the module. Debriefing process occurs in the last session.

Table 3 Frequency distributions of adolescent knowledge level before being given health education with media singing Goldapersas

\begin{tabular}{lcc}
\hline Category & Frequency & percentage \\
\hline Well & 23 & 41.8 \\
Enough & 31 & 56.4 \\
Less & 1 & 1.8 \\
\hline Total & 55 & 100.00 \\
\hline
\end{tabular}

Based on Table 3 shows that the level of knowledge before being given health education adolescent with singing Goldapersas category dominated by quite as many as 31 students (56.4\%).

The results showed that the level of knowledge of adolescents before being given health education with the singing Goldapersas media mostly have enough knowledge. This is because students ever to access information about reproductive health through the internet. Aligned to the research conducted by Walidaini \& Arifin (2016) entitled Use of the Internet To Learn On Student, said that the average utilization of the internet are on the appropriate category in which to learn to use the Internet. Thus, most of the students have access to information about reproductive health through the internet. Electronic media Internet became the main source in the search for information, especially for teenagers, this is in line with Dewi \& Wirakusuma (2017) in a study titled Knowledge and Premarital Sexual Behavior In Teens High School, knowledge or information acquired through sexual at most electronic media and the Internet that is equal to $74.1 \%$, at the level of sexual knowledge most have a good level of knowledge. Research Nur (2014) entitled Overview of Internet Usage In Finding Health Information In Junior high school students said that as many as $68.3 \%$ of 
students never seek health information through the Internet, with the majority of respondents claimed to look for health information at least once a month (49.2\%), once a week (38.1\%), and a day all (12.7\%). Thus, do not be surprised if the student most have been exposed to information through the Internet, so that knowledge was dominated by the category enough.

Table 4 Frequency distributions of adolescent knowledge level after the given health education with the singing Goldapersas

\begin{tabular}{lcc} 
Category & Frequency & percentage \\
\hline Well & 54 & 98.2 \\
Enough & 1 & 1.8 \\
Less & - & - \\
\hline Total & 55 & 100.00 \\
\hline
\end{tabular}

Based on Table 4 shows that the level of knowledge of adolescent health education is given after singing Goldapersas dominated both categories were 53 students (98.2\%).

The results showed that the level of knowledge of adolescent health education is given after singing Goldapersas media mostly had good knowledge. This research is in line with the results of the study Zahra (2014) with the title song Media Usage Effectiveness Learning Speaking Skills In German, stating that there are significant differences in learning achievement German language skills before and after (pretest-posttest) tracks media usage in learning the German language skills. Supported by another study conducted by Sandri (2018) entitled Effect of Media Songs on the Result of Learning Mathematics In the Material Attributes Bangun Datar Grade 5 elementary school Bengkulu city, said that the average value of students learning with media track higher than the average value of the students taught without the use of media song. When the delivery of health education with media researcher singing Goldapersas deliver material for 30 minutes. Respondents enthusiastically in singing, but there are some respondents who had difficulty in memorizing lyrics. There is a question and answer session where several students were asked about the material presented.
Table 5 Frequency distributions of adolescent knowledge level before being given health education leaflets media

\begin{tabular}{lcc}
\hline Category & Frequency & percentage \\
\hline Well & 26 & 47.3 \\
Enough & 29 & 52.7 \\
Less & - & - \\
\hline Total & 55 & 100.00 \\
\hline
\end{tabular}

Based Based on Table 5 According to the table shows that the level of knowledge of adolescents before being given health education leaflets media category was dominated by quite as much as 29 students $(52.7 \%)$.

The results showed that the level of knowledge of adolescents before being given health education leaflets media dominated the category enough, this is because the students have never had the subjects or health education on reproductive health of teachers and health professionals. Health education is one way to increase the knowledge of students or teenagers in line with research Ristaningsih (2017) entitled Effect of Health Education Against Adolescent Reproductive Health Knowledge Level, that effective health education improve knowledge on adolescent reproductive health with an average value of 1.84 pretest and posttest 2:54. in the study Widarma \& Hayati (2017) entitled Effect of Adolescent Health Counseling Against Knowledge About HIV / AIDS said that after being given health education knowledge was obtained almost all respondents (95\%) included both categories. Thus, the majority of respondents had not received health education so that their knowledge only makes up with enough category.

Table 6 Frequency distributions of adolescent knowledge level after given health education leaflets media

\begin{tabular}{lcc}
\multicolumn{1}{c}{ Category } & Frequency & percentage \\
\hline Well & 55 & 100.0 \\
Enough & - & - \\
Less & - & - \\
\hline Total & 55 & 100.00 \\
\hline
\end{tabular}

Based Based on Table 6 According to the table indicates that the level of knowledge of adolescents after given health education 
leaflets media were dominated by either category as many as 55 students (100\%).

The results showed that the level of knowledge of adolescents after given health education leaflets media all have a good knowledge. In harmony with the results of research Asfar \& Asnaniar (2018) entitled Effect of Health Education on Level of Knowledge and Attitudes About HIV / AIDS said that health education has significant impact on the level of knowledge of adolescents about HIV / AIDS, and there is increasing knowledge of adolescents one of them supported by the use of leaflets media. In addition to such research, (Sinuhaji, 2018) in his research entitled Efektiifitas Extension and Media Leaflet Against Knowledge and Attitudes Mother Toddlers About Malnutrition, saying that there were significant knowledge of Mrs. toddlers before and after health education by using media leaflet with the obtained value of $p$ $=0000$. When the delivery of health education by using media lealfet, delivery of material was performed for 30 minutes. Researchers distributing leaflets on each respondent. Respondents seemed enthusiastic in scrutinizing every sentence and a picture on the leaflet, it's just that there are a number of respondents were busy folding leaflets that had not listened to a bit of the material presented. Debriefing process occurs in the last session.

Table 7 Results of Kruskal Wallis difference in the effectiveness of media singing Goldapersas, modules and leaflets.

\begin{tabular}{lcc}
\hline \multicolumn{1}{c}{ variables } & $\begin{array}{c}\text { mean } \\
\text { Rank }\end{array}$ & $P$ \\
\hline chant & 65.17 & 0000 \\
Goldapersas & 105.55 & \\
Module & 78.27 & \\
leaflet & \\
\hline
\end{tabular}

Based on Table 7. shows that the effectiveness of pikma role in enhancing knowledge using the media singing Goldapersas, modules and leaflets can be seen from the results of significance Kruskal Wallis test were produced, with the provision that if the variable was declared differ significance Kruskal-Wallis test produced $<0: 05$. Based on the analysis results obtained $p$ value is 0.000 , it shows that there are differences in the level of knowledge between variables (singing Goldapersas, modules and leaflets) after being given health education.
From the mean rank obtained, indicating that the media module has a mean value of the highest rank in comparison to media and media singing Goldapersas leaflet is 105.55 .

The results showed that there are different levels of knowledge between variables (singing Goldapersas, modules and leaflets) after being given health education. Media module is more effective in increasing knowledge of adolescents about sex.

According to Notoatmodjo (2012) media or tools are arranged based on the principle that knowledge that exist in every human being received or captured through the five senses. Messages or knowledge received through different media have different intensities in understanding the message.

Media singing Goldapersas included in the category of hearing aids (audiovisual aids), which according Notoatmodjo (2012) can help stimulate the senses of hearing at the time of the receipt of the message. Goldapersas chant used in this study is a song that was composed of the lyrics contain material about sex. Goldapersas chant taught to respondents was equipped with the music. And when the delivery of content through song Goldapersas is running smoothly, just that there are some students have difficulty in memorizing lyrics.

Media module and leaflet included in the category of visual aids (visual aids) which, according to Notoatmodjo (2012) useful in helping to stimulate the senses of the eye (vision) at the time of the receipt of the message. Modules were used in conducting this study was designed in accordance with the material to be conveyed is about sex and equipped with pictures to facilitate understanding of the respondent. Delivery of content using this module run media conducive, where all the material can be delivered and students actively respond to text and images contained within the module.

The results showed that the modules media more effectively to support Pikma role in improving knowledge of adolescents about sex than the media and media singing Goldapersas leaflet.

These findings are consistent with the theory presented by Notoatmodjo (2012) namely that one of the benefits or media tools is to facilitate the receipt of the information. Existing knowledge on someone received through the senses, and according to experts, the senses most widely distribute knowledge 
are the senses the eye into the brain. Approximately $75 \%$ to $87 \%$ of human knowledge acquired or distributed through the eye. Media module in this study included the visual aids that help stimulate the senses of the eye (sight) at the time of the receipt of the message.

Thus the media module is more effective in supporting roles Pikma to increase knowledge about sex, according to the Student PIK scope covering one of which is TRIAD KRR (Sexuality, Napsa, HIV / AIDS) (BKKBN, 2009).

Conclusion and Suggestions. The knowledge level before being given health education adolescent with a media module that is largely sufficient knowledge of students in the category of a total of 29 students (52.7\%) and after the health education given to the media module that is mostly the students' knowledge in both categories as many as 55 students (100\%).

The level of knowledge of adolescents before being given health education with media singing Goldapersas ie most of the knowledge of students in a category quite as many as 31 students $(56.4 \%)$ and after given health education with media singing Goldapersas ie most of the knowledge of students in both categories as many as 53 students (98.2\%),

Adolescent knowledge level before being given health education leaflets media that is largely sufficient knowledge of students in the category of a total of 29 students $(52.7 \%)$ and health with leaflets media that is mostly the students' knowledge in the category of 55 students $(100 \%)$. Media module is more effective in supporting roles Pikma to increase knowledge about sex in adolescents.

Acknowledgements. Thanks to the researchers say to all those who have helped in completing this research.

\section{References}

Asfar, A. and Asnaniar, W. O. S. (2018) 'Pengaruh Penyuluhan Kesehatan Terhadap Tingkat Pengetahuan dan Sikap Tentang Penyakit HIV/AIDS Di SMP Baznas Provinsi Sulawesi Selatan', 3.

BKKBN (2009) 'Pusat Informasi dan Konseling Kesehatan Reproduksi Remaja ( PIKKRR )'.

BKKBN (2018) 'Pendidikan Kesehatan
Reproduksi Bagi Generasi Muda', pp. 24; 26.

BKKBN and BPS (2013) 'Survei Demografi dan Kesehatan Indonesia 2012 Kesehatan Reproduksi Remaja', Survei Demografi dan Kesehatan Indonesia, pp. 17; 86.

Dewi, N. L. P. R. and Wirakusuma, I. (2017) 'Pengetahuan dan Perilaku Seksual Pranikah pada Remaja SMA di Wilayah Kerja Puskesmas Tampaksiring I'.

Dinkes Magelang (2018) Data Masalah Remaja Kota Magelang Tahun 2018. Magelang: Dinkes Magelang.

Hasan, S. and Nasma, A. (2008) Lets Talk About Love. Solo: Tiga Serangkai.

Johariyah, A. and Mariati, T. (2018) 'Efektivitas Penyuluhan Kesehatan Reproduksi Remaja dengan Pemberian Modul Terhadap Perubahan Pengetahuan Remaja', Jurnal Manajemen Kesehatan Yayasan RS.Dr. Soetomo, 4(1), p. 38. doi: 10.29241/jmk.v4i1.100.

Kemenkes RI (2018) Profil Kesehatan Indonesia 2017. Jakarta: Kemenkes RI.

Kusuma, A. W. and Budiono, I. (2017) 'Media Modul Gizi Braille Terhadap Pengetahuan, Sikap, dan Praktik Makan Pagi pada Anak Tunanetra', 2.

Lembaga Demografi FEB UI (2017) 'Ringkasan Studi Prioritaskan Kesehatan Reproduksi Remaja Untuk Menikmati Bonus Demografi', Brief Notes Lembaga Demograf, pp. 2; 5 .

Luthfi, D. (2015) 'Perbedaan Pengetahuan Remaja Sebelum Dan Sesudah Diberikan Penyuluhan Tentang Gizi Seimbang Dengan Menggunakan Media Video Di SMP Negeri 2 Kartasura'.

Marmi (2015) Kesehatan Reproduksi. Yogyakarta: Pustaka Pelajar.

Notoatmodjo (2012) Promosi Kesehatan Dan Perilaku Kesehatan. Jakarta: Rineka Cipta.

Nur, L. (2014) 'GAmbaran Penggunaan Internet dalam Mencari Informasi 
Kesehatan Pada Siswa Sekolah Menengah Pertama (SMP) X', 28.

Ristaningsih, G. P. (2017) 'Pengaruh Pendidikan Kesehatan Terhadap tingkat Pengetahuan Kesehatan Reproduksi Remaja Pada Siswi Kelas VII di SMP Negeri 28 Semarang'.

Rofi'ah, S., Widatiningsih, S. and Vitaningrum, D. (2017) 'Efektivitas Pendidikan Kesehatan Metode Peer Group terhadap Tingkat Pengetahuan dan Sikap Personal Hygiene Saat Menstruasi', Jurnal IImiah Bidan, II(2), pp. 31-36. Available at: https://media.neliti.com/media/publication s/227226-efektivitas-pendidikankesehatan-metode-1c5102d8.pdf.

Sandri, M. (2018) 'Pengaruh Media Lagu Terhadap Hasil Belajar Matematika Pada Materi Sifat-sifat Bangun Datar Siswa Kelas 5 SD Negeri 5 Kota Bengkulu', 2.
Sinuhaji, L. N. B. (2018) 'Efektivitas Penyuluhan dan Media Leaflet terhadap Pengetahuan dan Sikap lbu Balita tentang Gizi Buruk di Dusun VII Desa Bangun Rejo Kecamatan Tanjung Morawa Utara Tahun 2018', Jurnal ilmiah Kohesi, 1(1). doi: 10.1016/j.worlddev.2018.08.012.

Walidaini, B. and Arifin, A. M. M. (2016) 'Pemanfaatan Internet Untuk Belajar Pada Mahasiswa'.

Zahra, D. (2014) 'Keefektifan Penggunaan Media Lagu Pada Pembelajaran Keterampilan Berbicara Bahasa Jerman Peserta Didik Kelas X di Madrasah Aliyah Negeri Purworejo'. 